\title{
Tensions and contradictions in Australian social policy reform: compulsory Income Management and the National Disability Insurance Scheme
}

\author{
Greg Marston, Sally Cowling, and Shelley Bielefeld
}

\begin{abstract}
This paper explores contemporary contradictions and tensions in Australian social policy principles and governmental practices that are being used to drive behavioural change, such as compulsory income management. By means of compulsory income management the Australian Government determines how certain categories of income support recipients can spend their payments through the practice of quarantining a proportion of that payment. In this process some groups in the community, particularly young unemployed people and Indigenous Australians, are being portrayed as requiring a paternalistic push in order to make responsible choices. The poverty experienced by some groups of income support recipients appears to be seen as a consequence of poor spending patterns rather than economic and social inequalities. By contrast, Australia's National Disability Insurance Scheme (NDIS) has been constructed as a person-centred system of support that recognises the importance of both human agency and structural investment to expand personal choices and control. Here we look at the rationale guiding these developments to explore the tensions and contradictions in social policy more broadly, identifying what would be required if governments sought to promote greater autonomy, dignity and respect for people receiving income support payments in Australia.
\end{abstract}

Keywords: income management, justice, disability insurance, social welfare policy, Indigenous peoples 


\section{Introduction}

This paper explores recent social policy reforms that have been developing over a similar time period in Australia: the National Disability Insurance Scheme (NDIS), and Compulsory Income Management (CIM). The NDIS has been framed by the Commonwealth Government as a major breakthrough for people with disabilities, enabling citizens to break free from decades of paternalism. By contrast, CIM reduces capacity for citizens on income support payments to self-determine how they spend the resources provided by the state. This means there are competing conceptions of human agency, social citizenship, and the role of the state informing major social policy reforms in Australia. This in itself is not unusual. The Australian welfare state is riddled with inconsistencies in terms of treatment of citizens and adequacy of coverage (Marston, McDonald \& Bryson 2013). What makes comparison between the NDIS and CIM both interesting and important is that it enables close scrutiny of the justification for paternalism and whether the differences between the NDIS and CIM are as great as they first appear, particularly in regard to choice and self-determination. While it is too early to undertake detailed comparison of practice in these programs, we can compare theoretical and philosophical justifications for social policy interventions in both cases to see how paternalism and self-determination are defined. The analytical task requires revisiting some of the reasons for state welfare, defined here in its broadest sense as the responsibility of the state to promote human wellbeing (Goodin 1998). Accordingly, the first part of our discussion briefly sketches some of the normative foundations of the modern welfare state. We then consider how different contemporary storylines emanating from these philosophical foundations are used in policy development to make the case for compulsory income management and the NDIS. The third aspect of the discussion looks at the features of the NDIS and CIM to highlight differences in principle and practice. The final part of the discussion considers the main policy actors and social movements advocating for change to income support policy and practice.

\section{Normative justifications for state welfare}

Good government is always fragile, always vulnerable to capture by special interests and self-serving elites, and always at risk of becoming detached from the people it is meant to serve. (Mulgan 2006: 13)

One source of legitimacy for modern states is the responsibility for welfare - a responsibility to promote wellbeing and reduce unnecessary suffering. While it has been the case that families and communities have played a role in meeting these needs, states present themselves as not just protectors, but also promoters of wellbeing (Mulgan 2006: 49). Ongoing debate in Australia and other Anglophone countries is not concerned with government involvement in welfare promotion, but how it should be achieved, and whether too much or too little government serves to help or hinder realisation of this goal. Residualists would construct the ethical state in terms of relieving palpable distress through safety 
net programs or merely correcting market failures, while socialists would place the emphasis on redistributive transfer programs that promote social equality (Goodin 1988: 5).

Welfare states have expanded and contracted depending on which ideal is being promoted at a given time. The commencement of the twenty-first century in Anglophone countries has seen the boundaries of the welfare state under attack in terms of government's role in meeting need. This onslaught has occurred in light of various versions of neoliberalism and the associated preference for market-based provision and a punitive approach to poverty governance, defined here as the social regulation of the poor through various programs and practices (Peck 2001). However, we should also recognise that the metaphor of state 'rollback' is misplaced when one considers the increase in state surveillance enabled by new technologies and that the proportion of Gross Domestic Product (GDP) dedicated to funding welfare state services in English-speaking countries has not radically reduced during the ascendency of neoliberalism (Castles 2004; Mendes 2009). The substantial change has been in the mixed economy of welfare, which refers to the involvement of the private, informal and non-profit sectors in the delivery of social policy and care services. Indeed, many western nation states now have a distinct preference for contracting out their obligations to promote welfare to a host of profit and non-profit agencies, obscuring the direct responsibilities of government (Powell 2007).

Social constructions of 'ideal government' are bound up with constructions of ideal citizenship - they mutually define each other. In the case of governing under conditions of neoliberalism the ideal citizen is one who takes personal responsibility and adopts self-sufficiency as a marker of autonomous adulthood (Brown 2015). Under neoliberalism, citizenship status moves from one who decides and acts collectively with others to gain preferred policy outcomes, to one reduced to the individualistic market role of consumer, worker, and paying customer (Crenson \& Ginsberg 2002). As Soss and colleagues (2011: 743 ) observe, 'Citizens ... have become synonymous with "taxpayers" who have a contractual right to expect efficient and effective institutional actions that produce a good return on their investment'. In this context, citizens are considered as consumers who pursue better goods from the system by exercising their individual freedom, rather than by joining others to participate in, or demand, improvements in the spaces and institutions we share. The flip side to this ideal is that governments that embrace this message feel justified in taking corrective action against those deemed to fall short of this measure. It is for this reason that governments can simultaneously espouse seemingly contradictory ideals and create hybrid forms of poverty governance. Soss and co-researchers (2011) refer to one potent form of hybrid poverty governance as 'neo-liberal paternalism', which captures the shared project of directive and paternalistic state programs that aim to transform the poor into self-funding and self-regulating subjects through market discipline.

This ethos of paternalism is interconnected with a now well-established idea labelled 'new paternalism', which claims that those who are impoverished suffer 
from defects of reason and/or character, and that they are less inclined to 'follow society's interests' (Mead 1997: 4). Advocates of such paternalism maintain that 'divergences from individual rationality in the economic sense will tend to be more frequent and severe among the poor than among the non poor' (Kleiman 1997: 190). Consequently, the goal of new paternalism, is not simply to punish misbehaviour, as the government defines it, but to prevent such behaviour pre-emptively 'by the oversight of authority figures, much as parents supervise their families' (Mead 1997: 5). Thus, the government has constructed supervisory social welfare policy that imposes conditions on the behaviour of the poor. Imposing conditionality on welfare recipients is linked to the idea that those who are dependent upon state support should not be able to enjoy freedom or privacy (Standing 2014: 325). Instead, new paternalism emphasises the 'obligations' of welfare recipients 'rather than their rights or needs' (Mead 1997: 21).

Libertarians, for whom ideal government means respecting privacy and promoting autonomy for citizens, are concerned about the implications of new paternalism for negative freedom - that is, freedom from unwarranted state interference (Standing 2001: 1-2, 274; 2014: 123-125, 384-385; Anderson \& Honneth 2005: 127-131). Other critiques make a distinction between weak and strong paternalism. Weak paternalism is defined as providing people with information in an attempt to change the means through which individuals achieve their own defined objectives. Strong paternalism, on the other hand, seeks to change the ends, that is, influence what people see as in their own interest (Thomas \& Buckmaster 2010). Strong paternalism can be justified, according to Goodin (1995), when it can be demonstrated that an individual's failed reasoning leads to behaviours that are contrary to their interests. New (1999), however, concludes that even despite the best of intentions, the state is limited in actually knowing an individual's interests better than the individual. 'Strong paternalism', dictating the means and ends of individual welfare, places a great deal of responsibility on the state to be publicly accountable and demonstrate that through directive social policy programs, like income management, it can be confident that it is doing more good than harm. In the case of compulsory income management, as we will discuss in the next section, the evidence is far from compelling on this point - raising a fundamental philosophical and practical question as to whether paternalism can be justified in the case of CIM policies.

What we can see from this brief discussion of reasons for welfare is that contemporary poverty governance is a mix of the old and the new. Income management animates old arguments about reasons for state welfare and the limits of government. However, in the context of a market economy it also ushers in new and individualised conceptions of a quasi-market citizen subject that appears decidedly hollow compared with solidaristic conceptions of citizenship, which by definition aim to strengthen social rights and seek to equalise the burdens and benefits of state welfare through risk-pooling mechanisms such as universal coverage. These competing conceptions are analytically useful when thinking about the merits of any social policy program, from conception through to implementation. 


\section{Implementing Compulsory Income Management}

What we want to do in this section is to reflect briefly on the history of compulsory income management and its implementation. Compulsory income management policy was initially implemented in 2007 as part of the Northern Territory Intervention via the Social Security and Other Legislation Amendment (Welfare Payment Reform) Act 2007 (Cth). CIM has since been modified and expanded in 2010, 2012 and 2015 by other legislative enactments. ${ }^{1}$ The earlier income management scheme directly targeted Indigenous welfare recipients, mostly those living in the Northern Territory. Under the more recent income management scheme these policies now apply to non-Indigenous as well as Indigenous Australians. However, Indigenous welfare recipients remain heavily over-represented in the new income management categories constructed by government under the 2010 legislation. As of 1 January 2016, 78 per cent of 26,347 welfare recipients subject to income management nationwide identified as Indigenous (Department of Social Services 2016b).

The underlying objectives of the current policy are apparent in the Explanatory Memorandum for the Social Security Legislation Amendment Act 2012 (Cth), which implements the 2012 extensions to the income management scheme. This states:

The income management regime ... operates as a tool to support vulnerable individuals and families. It provides a tool to stabilise people's circumstances by limiting expenditure of income support payments on excluded items, including alcohol, tobacco, pornography, gambling goods and activities. (Explanatory Memorandum, Social Security Legislation Amendment Bill 2011)

The purpose of the government in this policy framework is therefore ostensibly beneficial - it is intended that income management will help those subject to it.

Income management targets some rather than all welfare recipients. There are different categories of income management operating depending on geographical location. Under the legislation (Social Security and Other Legislation Amendment (Welfare Reform and Reinstatement of Racial Discrimination Act) Act 2010 (Cth)), compulsory income management categories were constructed and applied in the Northern Territory for those defined as 'disengaged youth', 'long-term welfare recipients', 'vulnerable' welfare recipients, those referred for 'child protection' issues, and those whose children do not comply with school enrolment and attendance requirements set by the government. In the place-based income management trials compulsory income management applies for the 'child protection' and 'vulnerable' categories. There is also a category of 'voluntary' income management. There are also now expansive referral powers for state and territory agencies. ${ }^{2}$ Such authorities can refer welfare recipients for CIM regardless of where they live.

More recently, the Australian Government has supported the trial of the 'Healthy Welfare Card'/Cashless Welfare Card via the Social Security Legislation Amendment (Debit Card Trial) 2015 Act (Cth). This was a key recommendation 
of the Indigenous Jobs and Training Review (Forrest 2014), commissioned by the Commonwealth from mining magnate Andrew Forrest. In 2016 the Cashless Welfare Card will be trialled in communities with significant Indigenous populations: Ceduna, Kununurra, and Wyndham (Department of Social Services 2016a). Eighty per cent of the welfare payments of the trial participants will be deposited on a Healthy Welfare debit card. This is a minor shift from the Forrest recommendation for a 'cashless' welfare system in which 100 per cent of all welfare payments would be quarantined (Forrest 2014: Chapter 2).

The Forrest Review gave no consideration to a now substantive evidence base on the limited impacts of BasicsCards and CIM on positive behavioural outcomes, and ignored evidence that it has created serious problems for numerous people subject to it (Bielefeld 2012, 2014a, 2014b, 2014/2015). Nor did the Forrest Review set out an argument as to why a cashless welfare system would drive healthier consumption choices. In his submission to the Indigenous Jobs and Training Review, which limited submissions to two pages, Altman (2014) opined:

The Forrest Review, philosophically, blends 1961 assimilation policy ideas with twenty-first century neoliberalism focusing on the individual and the family as if policy can be removed from the community and society and operating on the basis of economic rationalism alone.

The Healthy Welfare Card has also evoked the following criticism from Mick Gooda, the Aboriginal and Torres Strait Islander Social Justice Commissioner:

What is most perplexing is the government's apparent fascination with controlling the finances of Aboriginal and Torres Strait Islander peoples. Our mob are once again the guinea pigs in a trial program lacking any evidence base. As I outlined in my 2015 Social Justice and Native Title Report, where people have experienced benefits as a result of income management, the results have been modest when compared to their stated objectives. For many, income management results in few or no benefits, and a 'sense of loss of control, shame and unfairness'. Any possible benefit of the card must be weighed against the sense of disempowerment our people already face. It must be weighed against the stigma our people continue to face, and the restrictions placed on our basic rights and freedoms we fought so hard for (Gooda 2016).

The financial cost of income management to date is significant, an estimated ' $\$ 1$ billion' during the period '2005-06 to 2014-15' (Buckmaster, Ey \& Klapdor 2012: 34). A further rollout of income management and/or variations of income management will only escalate this cost. Other costs to factor in include the 'longer-term social costs' of such intrusive and punitive paternalism, which may well be 'greater than any savings made' (Standing 2014: 251). A Department of Social Services report claims that the role of government includes ensuring that 'taxpayer funds are well targeted' (Department of Social Services 2014: 
15). However, this remains questionable in the CIM context, given the lack of convincing evidence to justify continuation and extension of the scheme.

Income management was launched upon Australian welfare recipients with no evidence that it would be of benefit to them, and ten years later the income management system still does not appear to do what its advocates promise (Mendes et al. 2014; Bielefeld 2014a; 2014/2015). The evidence base for income management appears to be limited at best (Cox 2011). As Eva Cox states, 'the policy decisions being made do not reflect the limits of the evidence available, and yet the program is expanding' (2011: 88). The 2012 government-commissioned evaluation report of income management in the Northern Territory (NT) found that 'there is little indication that income management is itself effective in changing parenting behaviour, reducing addiction or improving capacity to manage finances' (Bray et al. 2012: 267). However, changing these factors has been repeatedly claimed by the government as the rationale underpinning income management (Dee 2014). The recent and most comprehensive NT Income Management Evaluation Report had even stronger findings, revealing there was no 'substantive evidence' that income management was achieving the government's key policy objectives or changing the behaviour of welfare recipients subject to it (Bray et al. 2014: xxi). Bray and others stressed:

There was no evidence of changes in spending patterns, including food and alcohol sales;

There was no evidence of any overall improvement in financial wellbeing, including reductions in financial harassment or improved financial management skills;

More general measures of wellbeing at the community level show no evidence of improvement, including for children; and

$[\mathrm{R}]$ ather than building capacity and independence, for many the program has acted to make people more dependent on welfare (2014: xxi-xxii).

Concerns also exist regarding the needs of women experiencing family violence who may be adversely affected by income management. The Australian Law Reform Commission has stated that income management may cause more problems than it resolves in such circumstances, and that it is not an appropriate means of addressing the needs of those who are experiencing vulnerability due to domestic violence (Australian Law Reform Commission 2011). This lies in direct contradiction to the government's ongoing claims that income management is a value-adding intervention for welfare recipients who are vulnerable.

Government-sponsored inquiries into reforming the income support system are much more cautious. The report A New System for Better Employment and Social Outcomes (2015) into Australia's income support system made the following recommendation: 'Income management should be used judiciously and should be delivered in conjunction with financial capability and other support services. Its outcomes need to be evaluated' (Department of Social Services 2015: 24). The fuller text discussing income management in the final report makes 
it clear that there are diverse views about the merits of income management. However, this report also stated:

Income management is part of a package of support services available to build skills for self reliance. It is an example of how the income support system is used to promote personal and family responsibility, particularly in relation to care of children, by ensuring a percentage of income support and family assistance payments are directed toward necessities including food, housing, utilities, clothing and medical care (Department of Social Services 2015: 114).

The paradox of managing someone's income to promote self-reliance echoes the sentiments of new paternalism and neoliberal paternalism discussed earlier. The statement also demonstrates how far the goals of the income support system have drifted from poverty relief towards an activation agenda. In the next section we discuss the reports and policy actors that have been driving the development of the NDIS to highlight how different framing of agency and responsibility is possible.

\section{The National Disability Insurance Scheme}

The shift to a National Disability Insurance Scheme (hereafter NDIS) originated from the 'Every Australian Counts' campaign by disability and carer sector organisations and other interest groups (Buckmaster \& Tomaras 2013: 15). The design of the NDIS owed much to the way in which the 18-month Productivity Commission Inquiry into Disability Care and Support was framed. The emphasis on economic and social participation and concern with costs and cost effectiveness are the standard markers of neoliberal reform agendas in the welfare and social policy spheres. Yet they were accompanied by terms of reference that explicitly referred to enhancing quality of life, entitlement to disability care, support services, and supporting choice.

The Commission's report established a case for change and placed explicit emphasis on facilitating a shift in decision-making to people with disability and their carers as a means to increase agency and control (Productivity Commission 2011: 5). In addition, the need to fund advocacy outside of the service provision network was highlighted, and a funder and assessor was recommended to avoid conflicts of interest (Productivity Commission 2011: 26). The Commission made particular reference to facilitating choice for people with disability with respect to who holds their funds and where they purchase services (2011: 18; Purcal et al. 2014: 88). There would 'not be one model that forced people to take all control or none' (2011: 30). The transition envisioned involves a shift from a service-centred arrangement in which people with disability are passive recipients, to a person-centred system in which people are citizens who are supported to 'think about what they might want from life and make decisions that help them get there' (Productivity Commission 2011: 344).

'Self-directed support' was preferred by the Commission to the term 'individualised funding'. This was defined to include resource allocation 
based on the individual's needs and aspirations (as opposed to an allocation based on meeting all preferences), the capacity for genuine and informed choice, access to individualised budgets, and the ability to tailor the mix and type of services received within this budget. Importantly, for this paper, the recommendation for self-directed funding was couched in terms of social norms such as self-determination and human rights. This is in line with the first general principle in Article 3(a) of the United Nations' Convention on the Rights of Persons with Disabilities, to which Australia is a signatory: 'respect for inherent dignity, individual autonomy including the freedom to make one's own choices and independence of persons' (United Nations, cited in Productivity Commission 2011: 355).

Purcal and colleagues (2014: 89) note the way in which 'choice' is a guiding tenet within both a neoliberal paradigm emphasing choice of providers in a free market, and a human rights framework emphasising choice by people with disability over their lifestyle and support services. In a review of the evidence on the impact of self-directed funding, the Productivity Commission (2011: Appendix E) highlighted the significant benefits flowing to people with disability from greater control over their budgets and lives in domains including greater responsiveness to needs, greater life satisfaction, more interaction with people and the community, and higher quality and continuity of care. The extent to which choice can be genuinely enabled under the NDIS will depend, in part, on how the market is structured and the adequacy of funds allocated to meet assessed needs and personal aspirations. Analysis of the implementation of the NDIS in pilot sites must explore these issues if tensions between alternative choice theories are to be reconciled.

Commentators have flagged a range of potential problems with the NDIS. Fawcett and Plath (2014: 753-754) have warned that transferring 'responsibility for choosing services to the individual ... carries the risk that the market will not deliver the required services.' This could leave people with disabilities worse off, particularly if such people also experience other types of complex structural disadvantage:

The market is under no obligation to respond to the wants and needs of individuals and will only do so if it is economically worth the effort. In relation to individual budgets, those who do well in negotiating with providers are likely to be those who are advantaged by education, English literacy, financial resources, gender, transport, geographic location, family supports and access to technology. (Fawcett \& Plath 2014: 754)

The situation of those experiencing 'social, environmental, logistical, communication, cultural and organisational barriers' could well turn out to be more precarious (Fawcett \& Plath 2014: 756). For instance, there are a specific set of concerns regarding access to services for 'people with intellectual disabilities from cultural and linguistically diverse backgrounds and those who cycle in and out of the criminal justice system' (Soldatic, van Toorn, Dowse \& Muir 2014: 6, 10-12). Additional concerns have been raised by Helen Dickinson 
(2015; 2016), who has questioned whether NDIS consumers will genuinely be enabled to choose services that meet their social needs.

Burton and Kagan (2006: 305) argue that in the context of the UK there are risks inherent in 'romanticism' about people with intellectual disability. While promoting a capacity for us to look beyond an identity defined by impairment, the UK approach does not provide for the investment required to enable inclusion, autonomy and choice to be realised in a meaningful way and to address barriers to employment on both the supply and demand sides. Burton and Kagan (2006) illustrate how the UK 'Valuing People' framework, which has many similar components to the NDIS, rubs up against the neoliberal program manifest in the income support system with its concern that welfare payments encourage dependency, without reference to structural barriers to employment and emphasis on individual responsibility over rights. The UK analysis points to the need for greater thinking about how we build operational and governance structures for the NDIS that support human interdependence and support systems integration - particularly with income support and employment systems - which enable the development of human capability.

The Productivity Commission made the case for an insurance rather than welfare scheme based on the need to pool risks and costs due to the inability of most individuals or families to prepare for the risk and financial impact of significant disability. This in turn requires major attitudinal and cultural change for the whole of the Australian population to partner in a successful NDIS (Walsh \& Johnson 2013: 334). A group of thinkers with expertise in disability policy, services and advocacy convened by PricewaterhouseCoopers (PwC) identified a crucial risk to the transformational vision of the NDIS as the need to equip stakeholders at each level of the system with the tools and resources necessary to build their capacity to negotiate fundamental change. Notions of 'choice' can quickly become empty rhetoric in the absence of evidence-based information to inform choice and supporting people with disability and their families to exercise meaningful choice. This will require person-centred and innovative ways of working by providers and staff who have traditionally operated under block grants, a preparedness to listen to and learn from the voices of clients, and tracking quality of life outcomes (PwC 2011: 30, 58). Importantly, the Productivity Commission does give consideration to the nature of the service environment and governance arrangements that support basic human needs - in this case of people with disability - for 'relatedness, competence and autonomy' (Homel \& Ryan 2010: 4). Attention is given to the need for service providers to understand the needs and aspirations of individuals, to offer choice and provide the supports that facilitate self-determination. It is telling that this is a very different set of policy principles for the NDIS than that underpinning CIM. However, the framing of the NDIS indicates that another form of social politics for income support is possible and indeed desirable, one where agency and autonomy are respected. 


\section{Opportunities for recognition, reform and resistance}

Greater synergy between disability reform and income support needs to start by acknowledging the differences in both process and outcomes. As discussed above, the NDIS had large and organised social movements pressing for change, which was supported by a robust inquiry on policy options and a Federal Government that supported the principles of self-determination and autonomy for people with a disability. People experiencing disability issues were framed as the 'deserving poor'. By comparison, income support rights and advocacy is poorly funded in Australia, which is not helped by the cultural injustice of the 'undeserving poor' discourse that continues to be the dominant lens through which issues of income support are predominantly discussed in the public sphere (Marston 2008).

In contrast, disability rights movements supported new thinking about capabilities and a demand for 'participation, empowerment and recognition' (Dean 2008: 7). The Productivity Commission did not frame the NDIS objectives in terms of independence or self-sufficiency, but instead recognised that human dignity required both autonomy and social inclusion. In other words, respect and dignity were powerful discursive frames in the reform agenda for the NDIS. In the case of compulsory income management the change was driven in a top-down fashion on the back of cultural myths and negative stereotypes about the unemployed, young people and Indigenous peoples.

This 'top-down' policy process associated with CIM has encountered resistance during its implementation phase. There are several themes central to this resistance of income management that are worth emphasising here for what they reveal about competing conceptions of the role of the state and the responsibility of citizens, including:

Income management unjustly stigmatises those who experience poverty as lacking capacity to budget or as anti-social and requiring attitudinal change.

Numerous welfare recipients subject to income management have felt angered and shamed by removal of their budgetary autonomy (Bray et al. 2012; Bray et al. 2014; Bielefeld 2014b).

Welfare conditionality imposed through income management replaces the concept of a right to welfare based upon need with behavioural constraints based upon negative stereotypes.

The philosophical underpinnings of income management suggest that individual welfare recipients are to blame for poverty rather than the structural factors over which they have no control (Bielefeld 2014/2015).

Administrative errors can occur, which leave welfare recipients unjustly impoverished (Bielefeld 2014a, 2014/2015).

There ought to have been a 'bottom-up' policy approach with a primary role for local communities in identifying problems and possible solutions (Mendes, Waugh, \& Flynn 2013: 24; Bielefeld 2012: 524; Banks, G., quoted in Cox 2011: 5). 
At a grassroots level, the Stop the Intervention Collective Sydney (STICS n.d.) and the Rollback the Intervention (n.d.) groups have been actively resisting a range of interventionist government policies that have affected Indigenous peoples since 2007, including income management. The broader income management scheme has been resisted in South Australia by Stop Income Management in Playford (SIMPla) through rallies, social media campaigns and demonstrations (SIMPla n.d.). There has been frontline worker opposition in the trial site in Western Sydney in 2013, where community workers refused to refer clients to Centrelink for income management:

[C]ommunity sector workers in Bankstown have been refusing to refer people as part of a boycott ... Child Protection workers in the Public Sector Association (PSA NSW) have voted for an industrial ban on referrals. Figures released ... show Bankstown has the lowest numbers of people on Income Management in the country (Solidarity Online 2013).

There is also a recently developed Keeping Income Management Accountable Network (National Welfare Rights Network 2014/2015: 22-23), which 'includes people from most of the place-based Income Management locations across Australia, and others, with an interest in sharing information and experiences about income management.'

The alliance between workers and citizen groups has the potential to achieve some policy concessions. However, unlike the partially successful resistance in the 1990s to the harsh 'breaching' (financial sanctions) income support regime (Marston \& McDonald 2007), no independent inquiry has been established. Clearly, more independent evaluation of placed-based income management trials is warranted. Indeed, as Mendes and fellow researchers (2014) illustrate, the consultants appointed by the government to undertake the evaluation of place-based income management mainly spoke with employees from federal and state government departments, and no representative from an NGO was appointed to either the steering committee or the advisory group overseeing the evaluation. Perhaps if the resistance to income management is to gather momentum it will need to return to first principles, which is what gave the social movement for the NDIS clarity and unifying purpose. The principle of autonomy and freedom from unwarranted state interference (negative freedom), for example, is something that can unite libertarians and social democrats alike (Standing 2014: 384).

A campaign based on autonomy and self-determination has a strong resonance in Indigenous politics (Bielefeld 2014a, 2014b); however, in mainstream social politics it encounters resistance when it confronts the argument that it is 'taxpayers' money' and therefore governments have a right to determine how it is spent. The discursive binary between taxpayers and welfare recipients is strong in Australia, which is reinforced by the institutional design of the welfare state whereby unemployment benefits are paid for out of general revenue. In cultural terms Australia embraces the paid work ethic to the point that all other socially productive activity is rendered virtually invisible (Beder 2000). Reframing these 
disrespectful discourses about people on income support payments is of course not a new challenge, or one that is unique to Australia. Writing in the context of the UK in the middle of the last century, Richard Titmuss argued that one way to confront these dividing practices was to insist on a broad definition of welfare and not to shy away from the dark side of social policy:

When we use the term social policy we must ... not automatically react by investing it with a halo of altruism, concern for others, concern about equality and so on. Nor must we unthinkingly conclude that because Britain - or any other country - has a social policy or has developed social services that they actually operate in practice to further the ends of progressive redistribution, equality and social altruism. What is 'welfare' for some groups may be 'illfare' for others (Titmuss 1974: 27).

A crucial aspect of Titmuss's analytical framework focuses on the 'social division of welfare'. Here policy makers are encouraged to think about the moral, political and technical distinctions between welfare provided to different categories of citizenship through different means and the implications for solidarity and social citizenship. Some forms of social policy - such as a complex and targeted income support system - have the capacity to divide the population, while others - such as public health or the National Disability Insurance Scheme, where risk is pooled - have the capacity to bind. More recent developments in political philosophy also offer a model of social justice focused on seeing connections between privilege and poverty in a way that seeks to expand the meaning of welfare by making a case for the moral imperative that justice is everyone's responsibility (Young 2011). This stands in stark contrast to a neoliberal discourse of self-sufficiency, productivity, reward, and individual blame.

We might conclude that those citizens who are not poor, at least at this point in time, participate in the same structure of advantage and disadvantage, constraint and enablement as those who fall below the poverty line at some point. This relational approach to social justice acknowledges that the line between vulnerable and resilient, or included and excluded, can change very quickly, particularly in times of personal illness, acquired disability, or widespread global economic uncertainty (Marston \& Dee 2015). It is after all a shared vulnerability that provides a moral foundation for state welfare, albeit one that accepts the inevitability of a certain degree of state paternalism that is part and parcel of pooling risk, but also one that resists the overreach of the state when it comes to determining means and ends for wellbeing.

It is difficult to argue against the proposition that we serve people's preferences better and serve them more effectively by tracing out the actual implications of their own life plans (Goodin 1988: 320). It is these kinds of narratives about self and society that have the potential to usher in a new social politics for income support recipients, but they must be nurtured and supported by a wide variety of policy actors and citizens. Moreover, lessons must be learned by observing how the NDIS reforms have made a more solidaristic conception of citizenship possible in Australian political discourse, one that recognises the vulnerabilities 
of all people, the interdependencies that make certain kinds of freedoms possible, and the obligations we have to each other, including strangers.

\section{Conclusion}

State welfare remains decidedly uneven in Australia; some citizens are compelled to do more, while others are given relative freedom to choose what they do and where they invest their time and resources. It is this hybrid form of governance that fits with Mitchell Dean's (1999) characterisation of social policy in Australia as 'authoritarian-liberalism', individual freedom for some and rigid authoritarianism for others. Moreover, the role of the state is conflicted in this space. The NDIS reforms construct the state as an 'enabler' (minimal interference), or what Bourdieu (1998: 2) calls the 'left hand of the state' (education, services, and support), while income management represents the state as punisher, strengthening the 'right hand of the state' and its disciplinary functions (penalisation of poverty, threat of sanctions).

The distribution of burdens and benefits among groups in society raises a significant social justice challenge, one that is as much cultural as it is material. The long-term unemployed, particularly young unemployed people, have always been considered the undeserving poor. What has changed with recent waves of income support reform is that more groups are now joining this category in an age of conditionality and sanctions whereby recipients of income support have become 'never-deserving citizens' (Marston \& McDonald 2007). The administrative burdens are increasing, while the material benefits of income support are being eroded. Although governments may try to diminish the number of people who need to present legitimate claims for state assistance, it is difficult to imagine a situation where no working-age people will need society's support and exemption from work. The reasons for this are varied and include structural barriers to finding employment such as discrimination and a shortage of suitable employment opportunities.

What is required are policy and practice settings that respond respectfully to the diversity of capabilities and aspirations of people living with and without a disability. In a social model of disability the disabling environment is privileged in understanding interactions between people living with a disability and social institutions as a way of ensuring other social actors share responsibility for processes of exclusion. In contrast, the construction of disadvantage in the income management policy framework locates the problem in people's psychology and poor choices. The structural context is lost in the quest to identify individual agency as the culprit and the cure. Compulsory income management is situated within what Harris and colleagues (2012: 824) define as an 'individualised model of citizenship that systematically ignores the social, economic and labour market conditions in which individuals seek employment'.

While the NDIS framework has aspects of a neoliberal model of consumer sovereignty, it also incorporates a human rights discourse and advances a social understanding of disability in which human agency and choice are essential to 
supporting inclusion, participation, and quality of life. This approach is more consistent with a socially connected model of responsibility and justice than the compulsory income management approach. The NDIS structure has more potential to challenge the effects of divisive classifications and restrictive limits on autonomy and freedom, recognising the autonomy and agency of all welfare recipients. Yet, as noted previously, the NDIS may also deliver less than it promises as concerns people with disabilities who experience a complex array of structural barriers to achieving full participation in society. On the surface at least, it appears that the NDIS is founded on an acknowledgement that addressing these barriers will not be achieved by a cajoling and controlling state that dictates the means and ends of welfare, as is the case with CIM. Revealing these contradictions in contemporary social policy reform will hopefully enable an unsettling of what has become a presumed truth in income support policy.

\section{References}

Altman, J. (2014) 'The Forrest Review: Creating Parity', Submission to the Indigenous Jobs and Training Review, Department of Prime Minister and Cabinet, 21 November.

Anderson, J. \& Honneth, A. (2005) 'Autonomy, Vulnerability, Recognition and Justice' in J. Christman and J. Anderson (eds.), Autonomy and the Challenges of Liberalism: New Essays, New York and Cambridge, Cambridge University Press.

Australian Law Reform Commission. (2011) Family Violence and Commonwealth Laws - Improving Legal Frameworks, Report No 117, Sydney, Commonwealth of Australia.

Beder, S. (2000) Selling the work ethic: from puritan pulpit to corporate PR, Scribe Publications, Melbourne.

Bielefeld, S. (2012) 'Compulsory Income Management and Indigenous Australians - Delivering Social Justice or Furthering Colonial Domination?’ University of New South Wales Law Journal, 35 (2), 545-562.

_ (2014a) 'Compulsory Income Management - Exploring Counter Narratives amidst Colonial Constructions of Vulnerability', Sydney Law Review, 36 (4), 695-726.

- $(2014 \mathrm{~b})$ 'Income Management and Indigenous Peoples - Nudged into a Stronger Future?', Griffith Law Review, 23 (2), 285-317.

— (2014/2015) 'Income Management, Indigenous Peoples and Structural Violence - Implications for Citizenship and Autonomy', Australian Indigenous Law Review, 18 (1), 99-118.

Bourdieu, P. (1998) Acts of Resistance: Against the Tyranny of the Market, New York, The New Press.

Bray, J. R., Gray, M., Hand, K., Bradbury, B., Eastman, C. \& Katz, I. (2012) Evaluating New Income Management in the Northern Territory: First Evaluation Report, Sydney, Social Policy Research Centre, UNSW. 
Bray, J.R., Gray, M., Hand, K., \& Katz, I. (2014) Evaluating New Income

Management in the Northern Territory: The Final Report, Sydney, Social Policy Research Centre, UNSW.

Brown, W. (2015) Undoing the Demos: Neoliberalism's Stealth Revolution, New York: Zone Books.

Buckmaster, L., Ey, C. \& Klapdor, M. (2012) 'Income Management: an Overview', Background Note, Parliamentary Library, Parliament of Australia.

Buckmaster, L. \& J. Tomaras. (2013) 'National Disability Insurance Scheme Bill 2012', Bills Digest No. 72 2012-13, Parliamentary Library: Parliament of Australia.

Burton, M. \& C. Kagan. (2006) 'Decoding Valuing People'. Disability and Society 21 (4), 299-313.

Castles, F.G. (2004) The Future of the Welfare State: Crisis Myths and Crisis Realities, Oxford, Oxford University Press.

Cowling, S. (2011) 'Using Compulsory Income Management to induce behavioural change: a case study in poor social policy', paper presented at Australian Social Policy Conference University of New South Wales.

Cox, E. (2011) 'Evidence-Free Policy Making? The Case of Income Management', Journal of Indigenous Policy, 12 (1), 1-89.

Crenson, M. \& Ginsberg, B. (2002) Downsizing democracy: How America Sidelined its Citizens and Privatized its Public. Baltimore, Johns Hopkins University Press.

Dean, H. (2008) 'Social Policy and Human Rights: Re-thinking the engagement'. Social Policy and Society, 7 (1), 1-12.

Dean, M. (1999) Governmentality: Power and Rule in Modern Society, Sage Publications, London. Crenson

Dee, M. (2014) Poverty by acronym in Australia: welcome to CIM, VIM, PBIM, CPIM and SEAM, Challenging Identities, Institutions and Communities: Refereed Proceedings of the TASA 2014, 1-16.

Department of Social Services (2014) A new system for better employment and social outcomes: Interim Report of the Reference Group on Welfare Reform to the Minister for Social Services, Canberra, Commonwealth of Australia.

- (2015) A New System for Better Employment and Social Outcomes: Report of the Reference Group on Welfare Reform to the Minister for Social Services (Final Report), Canberra, Commonwealth of Australia.

— (2016a) 'Cashless Debit Card Trial - Overview', https://www.dss.gov.au (accessed 21 October 2016).

_ (2016b) 'Income Management Summary Data (1 January 2016)', http://data. gov.au/dataset (accessed 21 October 2016).

Dickinson, H. (2015) 'Is Australia ready to give people with disability real choice and control over services?', The Conversation, 24 November, http:// theconversation.com (accessed 21 October 2016). 
- (2016) 'Will the NDIS and individualisation of disability services enhance human rights?', Power to Persuade, 1 March, http://www.powertopersuade. org.au (accessed 21 October 2016).

Explanatory Memorandum, Social Security Legislation Amendment Bill 2011 (Cth). Fawcett, B. \& Plath, D. (2014) 'A national disability insurance scheme: What social work has to offer'. British Journal of Social Work 44, 747-762.

Forrest, A. (2014) The Forrest Review: Creating Parity, Commonwealth of Australia.

Gooda, M. (2016) 'Government's Healthy Welfare Card no solution to alcohol abuse', The Australian, January 25, http://www.theaustralian.com.au/opinion (accessed 21 October 2016).

Goodin, R. (1995) Utilitarianism as a public philosophy, Cambridge University Press, Cambridge.

— (1988) Reasons for welfare, Princeton, Princeton University Press.

Grover, C. \& Soldatic, K. (2013) 'Neoliberal restructuring: disabled people and social (in)security in Australia and Great Britain', Scandinavian Journal of Disability Research, 15 (3), 216-232.

Harris, S. Owen, R. \& Gold, R. (2012) 'Parity of participation in liberal welfare states: human rights, neo liberalism, disability and employment'. Disability and Society, 27 (6), 823-836.

Homel, J. \& Ryan, C. (2010) 'Incentives, rewards, motivation and the receipt of income support' Social Policy Evaluation, Analysis and Research Centre: FaHCSIA Occasional Paper No. 32, Canberra: Australian Government Department of Families, Housing, Community Services and Indigenous Affairs.

Kleiman, M. (1997) 'Coerced Abstinence: A Neopaternalist Drug Policy Initiative' in L. Mead (ed.) The New Paternalism: Supervisory Approaches to Poverty, Washington D.C., Brookings Institution Press.

Marston, G. (2008) 'A War on the Poor: Constructing Welfare and Work in the $21^{\text {st }}$ Century’, Critical Discourse Studies, 5 (4), 359-370.

Marston, G. \& McDonald, C. (2007) 'Assessing the policy trajectory of welfare reform in Australia'. Benefits, 15 (3), 233-245.

Marston, G. McDonald, C. \& Bryson, L. (2013) The Australian Welfare State: Who Benefits Now?, Melbourne, Palgrave MacMillan.

Marston, G. \& Dee, M. (2015) 'Old wine in new bottles: a critical appraisal of the social inclusion agenda in Australia', Australian Journal of Social Issues, 50 (2), 119-138.

Mead, L. (1997) 'The Rise of Paternalism' in L. Mead (ed.) The New Paternalism: Supervisory Approaches to Poverty, Washington D.C., Brookings Institution Press.

Mendes, P., Waugh, J. \& Flynn, C. (2013) 'A community development critique of compulsory income management in Australia' Alternativas. 20, 23-40. 
- (2014) 'Income management in Australia: a critical examination of the evidence', International Journal of Social Welfare, 23 (4), 362-372.

Mendes, P. (2009) 'Retrenching or renovating the Australian welfare state: the paradox of the Howard government's neo-liberalism', International Journal of Social Welfare, 18 (1), 102-110.

Mulgan, G. (2006) Good and Bad Power: The Ideals and Betrayals of Government, London; New York: Allen Lane.

National Welfare Rights Network (2014/2015) Annual Report July 2014 to June 2015 http://www.welfarerights.org.au (accessed 21 October 2016).

New, B. (1999) 'Paternalism and Public Policy', Economics and Philosophy, 15 (1), 63-83.

Peck, J. (2001) Workfare States, London: Guilford Press.

Powell. M. (ed.) (2007) Understanding the Mixed Economy of Welfare, Bristol, Policy Press.

PricewaterhouseCoopers (2011) Disability expectations: Investing in a better life, a stronger Australia. PwC (November).

Productivity Commission (2011) Disability Care and Support, Melbourne, Productivity Commission.

Purcal, C., Fisher, K.R. \& Laragy, C. (2014) 'Analysing Choice in Australian Individual Funding Disability Policy.' Australian Journal of Public Administration, 73 (1), 88-102.

Rollback the Intervention, http://rollbacktheintervention.wordpress.com/ (accessed 21 October 2016).

Social Security and Other Legislation Amendment (Welfare Payment Reform) Act 2007 (Cth).

Social Security and Other Legislation Amendment (Welfare Reform and Reinstatement of Racial Discrimination Act) Act 2010 (Cth).

Social Security Legislation Amendment Act 2012 (Cth).

Social Services Legislation Amendment (No. 2) Act 2015 (Cth).

Social Security Legislation Amendment (Debit Card Trial) 2015 Act (Cth).

Soldatic, K., van Toorn, G., Dowse, L. \& Muir, K. (2014) 'Intellectual Disability and Complex Intersections: Marginalisation under the National Disability Insurance Scheme', Research and Practice in Intellectual and Developmental Disabilities, 1(1), 6-16.

Solidarity Online 'Income Management expansion in effort to break boycott', 18 April 2013, http://www.solidarity.net.au/aboriginal/ income-management-expansion-in-effort-to-break-boycott/.

Soss, J., Fording, R. \& Schram, S. (2011) Disciplining the Poor-Neoliberal Paternalism and the Persistent Power of Race, Chicago \& London, University of Chicago Press.

Standing, G. (2014) A Precariat Charter - From Denizens to Citizens, London \& New York, Bloomsbury. 
— (2001) Beyond the New Paternalism: Basic Security as Equality, London and New York, Verso.

Stop Income Management in Playford (SIMPla), www.facebook.com/

SIMPlaStopIncomeManagementinPlayford (accessed 21 October 2016).

Stop the Intervention Collective Sydney (STICS), www.stoptheintervention.org (accessed 21 October 2016).

Thomas, L. \& Buckmaster, T. (2010) Paternalism in social policy: when is it justifiable? Research Paper no. 8 2010-11, http://www.aph.gov.au (accessed 21 October 2016).

Titmuss, R. (1974) 'Social Policy: An Introduction', in Social Policy, eds B. Abel-Smith \& K. Titmuss, London, Allen \& Unwin.

Walsh, J. \& Johnson, S. (2013) 'Development and Principles of the National Disability Insurance Scheme.' Australian Economic Review, 46 (3), 327-337.

Williams, R. (2013) 'Policy Forum: Disability Care and Support - Introduction.' Australian Economic Review, 46 (3), 325-326.

Young, I.M. (2011) Responsibility for Justice, Oxford, Oxford University Press.

\section{Endnotes}

${ }^{1}$ Social Security and Other Legislation Amendment (Welfare Reform and Reinstatement of Racial Discrimination Act) Act 2010 (Cth); Social Security Legislation Amendment Act 2012 (Cth); Social Services Legislation Amendment (No. 2) Act 2015 (Cth).

${ }^{2}$ Section 6 of Part 1 of Schedule 1 of the Social Security Legislation Amendment Act 2012 (Cth) amends the Social Security (Administration) Act 1999 (Cth) and inserts s 123TGAA, which gives the Minister power to declare that a department (a), body (b), or agency (c) is a 'recognised State/Territory authority' for the purposes of referral for compulsory income management. 